\title{
Muscle fibre characteristics and lactate responses to exercise in chronic fatigue syndrome
} Russell J M Lane, Michael C Barrett, David Woodrow, Jill Moss, Robert Fletcher,
Leonard C Archard pathogenesis, and many theories concerning its origins have been proposed. ${ }^{2}$ One area of contention is the possibility that neuromuscular dysfunction may contribute to the fatigue in some cases. In general, muscles in patients with chronic fatigue syndrome do not exhibit characteristics of physiological fatigue or reduced static muscle strength. ${ }^{3}{ }^{4}$ However, neuromuscular abnormalities, including disordered muscle energy metabolism on phosphorus magnetic resonance spectroscopy, ${ }^{5-7}$ abnormalities on single fibre electromyography, ${ }^{8-10}$ and various non-specific histological, histometric, and ultrastructural abnormalities on muscle biopsy, have been reported in some patients with chronic fatigue syndrome (table 1$) \cdot{ }^{10-18}$ Previous studies of incremental exercise indicated a "left shift" in anaerobic threshold in some patients with chronic fatigue syndrome, with a premature increase in plasma lactate concentrations at low work rates. ${ }^{19}$ We reported subsequently that 31 of $96(32 \%)$ consecutive patients with chronic fatigue syndrome had abnormal lactate responses to a short period of exercise at work rates below the predicted anaerobic threshold. ${ }^{20}$ Whereas this may have been due to the effects of inactivity, patients with abnormal lactate responses showed no more evidence of cardiovascular deconditioning than those with normal responses, and were less likely to have psychiatric disorders. Eighty four of these patients underwent muscle biopsy. In this paper, we report the histometric analysis of the biopsies in relation to the lactate responses to exercise, together with findings in an additional 21 cases ascertained subsequently. The findings are discussed in relation to previous observations on muscle biopsy changes in chronic fatigue syndrome, and we consider the issue of whether the changes reflect the effects of inactivity alone or some additional pathological process.

(F Neurol Neurosurg Psychiatry 1998;64:362-367)

Keywords: chronic fatigue syndrome; muscle; lactate; exercise responses

Chronic fatigue syndrome comprises disabling fatigue, present for more than six months, together with symptoms that feature prominently impairments in concentration and short term memory, sleep disturbances, musculoskeletal pain, and exertional intolerance, in the absence of definable medical or psychiatric disorders. ${ }^{1}$ It is likely that a condition with such wide ranging and non-specific symptoms will prove to be heterogenous in aetiology and
Patients and methods

ASCERTAINMENT OF PATIENTS

The 96 patients in the original cohort fulfilled operative criteria for the diagnosis of chronic fatigue syndrome (Oxford criteria ${ }^{21}$ ). Eighty four patients underwent needle biopsy from the left quadriceps under local anaesthetic; the remainder either refused biopsy or the attending physicians requested that this procedure should not be performed. Subsequently, an additional 21 patients with chronic fatigue syndrome were ascertained and studied in a similar way, giving a total of 105 cases. 
Table 1 Histological and histometric findings in patients with chronic fatigue syndrome

\begin{tabular}{|c|c|c|c|c|}
\hline Authors & $\begin{array}{l}\text { No of patients } \\
\text { biopsied/studied }\end{array}$ & Histology & Histometry & Other findings and comments \\
\hline Behan et al $(1985)^{11}$ & $20 / 50$ & $15 / 20$ scattered necrotic fibres & $\begin{array}{l}\text { Moderate type } 2 \text { fibre predominance } \\
\text { and hypertrophy in all }\end{array}$ & $\begin{array}{l}\text { Conspicuous increase in } \\
\text { peripheral mitochondria and } \\
\text { occasional tubular } \\
\text { inclusions. } 30 / 40 \text { abnormal } \\
\text { jitter on SFEMG, } 6 / 6 \\
\text { abnormal magnetic } \\
\text { resonance spectroscopy of } \\
\text { muscle }\end{array}$ \\
\hline Byrne et al $(1985)^{12}$ & $2 / 2$ & Normal & $\begin{array}{l}\text { Type } 2 \text { atrophy in both consistent with } \\
\text { disuse }\end{array}$ & $\begin{array}{l}\text { Mild reduction in state } 3 \\
\text { respiration on polarography } \\
\text { of isolated mitochondria }\end{array}$ \\
\hline $\begin{array}{l}\text { Byrne and Trounce } \\
(1987)^{13}\end{array}$ & $11 / 11$ & Minicore change in one case & $10 / 11$ normal or mild $2 b$ fibre atrophy & $\begin{array}{l}\text { Glycolytic and } \\
\text { mitochondrial enzymes } \\
\text { normal in vitro }\end{array}$ \\
\hline $\begin{array}{l}\text { Karpati et al } \\
(1990)^{14}\end{array}$ & ? & $\begin{array}{l}\text { Slight excess of central myonuclei, scattered small } \\
\text { fibres in most. No inflammation }\end{array}$ & & $\begin{array}{l}\text { Striking MHC class I } \\
\text { expression in } 2 \text { cases }\end{array}$ \\
\hline Behan et al $(1991)^{15}$ & $50 / 50$ & $\begin{array}{l}3 \text { cases occasional necrotic fibres. } 2 \text { cases tiny } \\
\text { inflammatory foci. } 4 \text { cases regenerative changes. } 25 \\
\text { cases prominent mitochondria on Gomori stain }\end{array}$ & $\begin{array}{l}39 / 50 \text { mild and focal ( } 6 \text { cases) to } \\
\text { severe and diffuse ( } 33 \text { cases) type } 2 \\
\text { atrophy. } 4 \text { cases type } 1 \text { atrophy }\end{array}$ & $\begin{array}{l}40 / 50(80 \%) \text { cases showed } \\
\text { structural mitochondrial } \\
\text { abnormalities }\end{array}$ \\
\hline Grau et al $(1992)^{16}$ & $20 / 20$ & $\begin{array}{l}\text { 9/20 non-specific abnormalities, including scattered } \\
\text { small or necrotic fibres, abnormal oxidative enzyme } \\
\text { staining, focal myofibrillar loss }\end{array}$ & $3 / 20$ type 2 hypertrophy & $\begin{array}{l}0 / 20 \text { MHC class } I \\
\text { expression }\end{array}$ \\
\hline $\begin{array}{l}\text { Preedy et al } \\
\quad(1993)^{17}\end{array}$ & $23 / 23$ & $\begin{array}{l}2 \text { cases had occasional split fibres, } 2 \text { others } \\
\text { centronuclear chains }\end{array}$ & $\begin{array}{l}3 / 20 \text { type } 2 \text { atrophy, } 5 \text { others } \\
\text { hypertrophy of one or both fibre types }\end{array}$ & $\begin{array}{l}\text { Significant reduction in } \\
\text { muscle RNA/DNA } \\
\text { composition }(15 \%) \text { but not } \\
\text { muscle protein/DNA ratio }\end{array}$ \\
\hline $\begin{array}{l}\text { Edwards et al } \\
\quad(1993)^{18}\end{array}$ & $74 / 74$ & Non-specific abnormalities in $81 \%$ of cases & $\begin{array}{l}27 \% \text { low prevalence, } 12 \% \text { high } \\
\text { prevalence of type } 1 \text { fibres, } 5 / 74 \text { fibre } \\
\text { atrophy or hypertrophy }\end{array}$ & $\begin{array}{l}\text { Similar abnormalities in } 1 / 3 \\
\text { of normal control biopsies, } \\
\text { TA studied in most cases }\end{array}$ \\
\hline $\begin{array}{l}\text { Connolly et al } \\
\quad(1993)^{10}\end{array}$ & $26 / 35$ & $\begin{array}{l}\text { Non-specific abnormalities in } 9 / 10 \text { cases with } \\
\text { prominent myalgia cf. } 3 / 16 \text { other CFS cases }\end{array}$ & & $\begin{array}{l}\text { Abnormal biopsy findings in } \\
\text { CFS cases with prominent } \\
\text { myalgia associated with } \\
\text { increased fibre density on } \\
\text { SFEMG, EDC biopsied in } \\
\text { all cases }\end{array}$ \\
\hline
\end{tabular}

SFEMG=Single fibre electromyography, $\mathrm{TA}=$ tibialis anterior, $\mathrm{EDC}=$ extensor digitorum communis.

LACTATE RESPONSES TO EXERCISE

All patients undertook a subanaerobic threshold exercise test (SATET) as described previously. ${ }^{22}$ Briefly, the anaerobic threshold was determined for each subject based on their age, weight, and sex, and patients exercised at $90 \%$ of this predicted work rate for 15 minutes. Venous lactate concentrations were determined before and immediately after

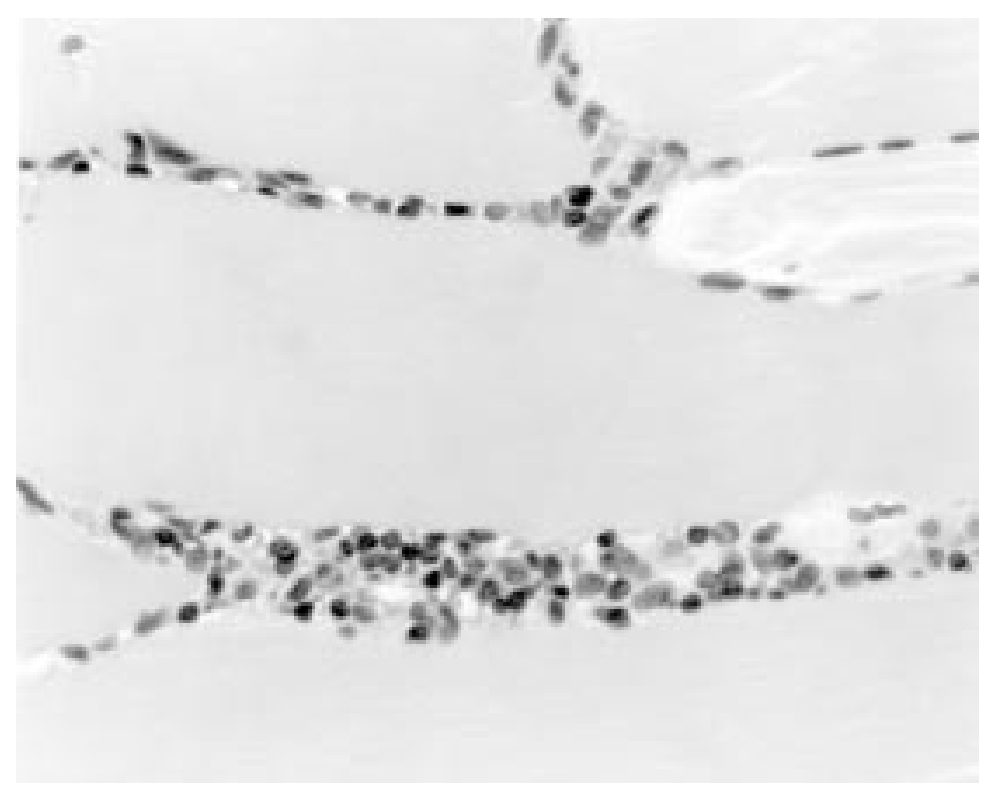

Longitudinal section from needle muscle biopsy, showing focal inflammation comprising $T$ lymphocytes and macrophages. This 44 year old man was investigated three years after developing chronic fatigue syndrome, characterised by prominent myalgia after a flu-like illness. There were no abnormal signs on examination. His serum creatine kinase was mildly increased at 304 (normal<150) IU/l and SATET was abnormal. (haematoxylin and eosin originally $\times 400)$. exercise, and 30 minutes after exercise. An abnormal SATET was defined as one in which lactate responses exceeded the upper $99 \%$ confidence limits at two or more time points $($ SATET+ve).

\section{MUSCLE BIOPSY STUDIES}

Biopsy samples were snap frozen in isopentane cooled in liquid nitrogen and prepared for histological and histochemical analysis using standard procedures. ${ }^{24}$ Portions were also prepared for ultrastructural examination. Histometric analyses were performed on histochemical preparations using ATPase $\mathrm{pH}$ 9.4, the observer (MB) being blinded as to the patients' diagnoses. Slides were viewed with a $\times 16$ or $\times 25$ objective on a Leitz Dialux microscope fitted with a drawing tube attachment. This arrangement permitted simultaneous viewing of sections and the surface of an $x-y$ coordinate digitising tablet (WACOM Ultrapad). Diameters of type 1 and type 2 muscle fibres were measured using the NIH-Image v1.6 software package (NIH-Image is in the public domain and is available from the URL http://www:rsb.info.nih.gov/nih-image or FTP: zippy.nimh.nih.gov/pub/nih-image) on a Power Macintosh 7100/66 computer. Measurements were made of fibres in contiguous groups so that the fibre type proportions were automatically obtained. The system was calibrated using a ruled slide (Graticules Ltd) and the calibration checked across the viewing field in all planes. Type 1 fibre predominance was deemed to be present if the percentage of type 1 fibres exceeded $55 \%$, and type 2 predominance if type 2 fibres exceeded $80 \%{ }^{24}$ 
Table 2 Histometric analysis of needle muscle biopsies from the vastus lateralis in 105 patients with chronic fatigue syndrome, ( $(\%)$ of cases to nearest whole number)

\begin{tabular}{llllll}
\hline $\begin{array}{l}\text { Type 1 } \\
\text { Predominance }\end{array}$ & $\begin{array}{l}\text { Type 1 } \\
\text { Atrophy }\end{array}$ & $\begin{array}{l}\text { Type 1 } \\
\text { Hypertrophy }\end{array}$ & $\begin{array}{l}\text { Type 2 } \\
\text { Predominance }\end{array}$ & $\begin{array}{l}\text { Type 2 } \\
\text { Atrophy }\end{array}$ & $\begin{array}{l}\text { Type 2 } \\
\text { Hypertrophy }\end{array}$ \\
\hline $24(23)$ & $4(4)^{\star}$ & $34(32) \dagger$ & $3(3)$ & $7(7)^{\star}$ & $25(24) \dagger$ \\
\hline
\end{tabular}

* Two cases both type 1 and type 2 atrophy.

$\dagger 13$ cases both type 1 and type 2 hypertrophy.

Atrophy and hypertrophy factors were calculated for type 1 and type 2 fibres by the method of Brooke and Engel, as summarised by Dubowitz. ${ }^{24}$ Fibre atrophy and hypertrophy were considered to be present if these limits were exceeded.

\section{STATISTICAL ANALYSIS}

Data for percentages of type 1 and type 2 fibres were normally distributed and between sample differences in distribution were analysed with Welch's $t$ test (two tailed), which does not assume equal sample variances. Data for atrophy and hypertrophy factors were compared using the Mann-Whitney $U$ test (two tailed). $p$ Values $<0.05$ were considered significant.

\section{Results}

The 105 patients comprised 48 men and 57 women, of mean age 35.7 (SD 10.9) years. Thirty nine of 105 (37\%) patients had abnormal lactate responses to exercise (SATET+ve). Histological and histochemical abnormalities were rare. One patient had an inflammatory infiltrate (figure), and nonspecific abnormalities, such as occasional necrotic fibres and scattered atrophic fibres were seen in a few cases, as noted previously by others (table 1), but there were no consistent changes. Table 2 shows the histometric analysis for the entire patient group. Only 11 of 105 $(10.4 \%)$ cases had muscle fibre atrophy, affecting type 1 fibres in four cases, type 2 fibres in two, and both in two cases. Muscle fibre hypertrophy was more common, being found in 59 cases $(56.2 \%)$. Type 1 and type 2 fibres were affected with similar frequency, with both fibre types showing hypertrophy in 13 of 59 cases $(22 \%)$.Type 1 predominance was found in $23 \%$ cases overall, compared with only $3 \%$ showing type 2 predominance. Table 3 compares the histometric data in patients with abnormal SATET with findings in patients with normal lactate responses to exercise. The average atrophy and hypertrophy factors for type 1 and type 2 fibres did not differ significantly in these two groups, but patients, particularly women, with abnormal lactate responses to exercise (SATET+ve) had significantly fewer mitochondria rich type 1 muscle fibres (men 40.1 (SD 13.5)\% v 48.0 (SD $12.3 \%$ ), $\mathrm{p}=0.043$; women 37.3 (SD 10.1) $v$ 50.4 (SD 13.9)\%, p<0.0003). In addition, SATET+ve women had a significantly higher mean type 2 fibre hypertrophy factor (333.4 (SD 343.9) v 134.5 (SD 241.3), $\mathrm{p}=0.013)$. It should be noted, however, that there was only a relative deficiency of type 1 fibres in the SATET+ve patients; absolute type 1 fibre deficiency ( $<20 \%$ type 1 fibres) was seen in only three SATET +ve patients $(7.7 \%)$, and in none of the SATET-ve patients. This relative deficiency of type 1 fibres was more pronounced in those SATET+ve patients with the most pronounced abnormal lactate responses to exercise (raised baseline lactate and/or postexercise lactate $>6 \mathrm{mM}$, table 4 ) (men 32.0 (SD 10.4)\% v 48.0 (SD 12.3)\%, $\mathrm{p}=0.011$; women 35.3 (SD 9.9)\% v 50.4 (SD 13.9)\%, $\mathrm{p}<0.0017)$. In this subgroup analysis, SATET+ve women again showed the trend to type 2 hypertrophy found in the overall chronic fatigue syndrome patient group (table 3) (411.6 (SD 434.2) v 134.5 (SD 241.3), $\mathrm{p}<0.06)$. Examination of electron microscopic

Table 3 Comparison of histometric data in relation to lactate responses to exercise, (mean (SD) for type 1 and type 2 fibre composition, atrophy, and hypertrophy factors)

\begin{tabular}{|c|c|c|c|c|c|c|}
\hline & \% Type 1 & \% Type 2 & $\begin{array}{l}\text { Type } 1 \\
\text { atrophy } \\
\text { factor }\end{array}$ & $\begin{array}{l}\text { Type } 1 \\
\text { hypertrophy } \\
\text { factor }\end{array}$ & $\begin{array}{l}\text { Type } 2 \\
\text { atrophy } \\
\text { factor }\end{array}$ & $\begin{array}{l}\text { Type } 2 \\
\text { hypertrophy } \\
\text { factor }\end{array}$ \\
\hline Upper normal limit & 55 & 80 & $M=150, F=100$ & $M=150, F=400$ & $M=150, F=200$ & $\mathrm{M}=400, \mathrm{~F}=150$ \\
\hline \multicolumn{7}{|l|}{ SATET +ve: } \\
\hline Men $(n=22)$ & 40.1 (13.5) & $59.9(13.5)$ & $49.8(74.2)$ & $233.6(323.5)$ & $45.8(52.6)$ & $250(333.9)$ \\
\hline Women $(n=17)$ & $37.3(10.1)$ & $62.7(10.1)$ & $7.2(8.8)$ & $436.1(360.3)$ & 41 (81.9) & $333.4(343.9)$ \\
\hline \multicolumn{7}{|l|}{ SATET -ve: } \\
\hline Men $(n=26)$ & $48.0(12.3)$ & $52.0(12.3)$ & $55.0(104.2)$ & $168.9(176.7)$ & $72.0(132.2)$ & $271.9(403.6)$ \\
\hline Women $(\mathrm{n}=40)$ & $50.4(13.9)$ & $49.6(13.9)$ & $12.8(26.3)$ & $353.7(488)$ & $56.2(80.6)$ & $134.5(241.3)$ \\
\hline \multicolumn{7}{|c|}{$\begin{array}{l}\text { SATET +ve } v \text { SATET -ve } \\
\text { (p value): }\end{array}$} \\
\hline Men & 0.043 & 0.043 & 0.63 & 0.49 & 0.793 & 0.64 \\
\hline Women & 0.0003 & 0.0003 & 0.90 & 0.17 & 0.18 & 0.013 \\
\hline
\end{tabular}

Table 4 Histometric comparison of patients with increased lactates at rest or $>6 m M$ after exercise, with patients with normal lactate responses to exercise (SATET-ve, table 3)

\begin{tabular}{lllllll}
\hline & & & $\begin{array}{l}\text { Type 1 } \\
\text { atrophy } \\
\text { factor }\end{array}$ & $\begin{array}{l}\text { Type 1 } \\
\text { hypertrophy } \\
\text { factor }\end{array}$ & $\begin{array}{l}\text { Type 2 } \\
\text { atrophy } \\
\text { factor }\end{array}$ & $\begin{array}{l}\text { Type 2 } \\
\text { hypertrophy } \\
\text { factor }\end{array}$ \\
\hline $\begin{array}{l}\text { Upper normal limit } \\
\text { SATET +ve (mean (SD)): }\end{array}$ & 55 & 80 & $\mathrm{M}=150, \mathrm{~F}=100$ & $\mathrm{M}=150, \mathrm{~F}=400$ & $\mathrm{M}=150, \mathrm{~F}=200$ & $\mathrm{M}=400, \mathrm{~F}=150$ \\
$\quad \begin{array}{l}\text { Men (n=6) } \\
\text { Women (n=9) }\end{array}$ & $32(10.4)$ & $68(10.4)$ & $45.2(59.7)$ & $447.7(531.3)$ & $36.5(53.9)$ & $442.2(574.2)$ \\
$\begin{array}{l}\text { SATET +ve } v \text { SATET -ve } \\
\quad \text { p value) }\end{array}$ & $35.3(9.9)$ & $64.7(9.9)$ & $10.0(9.94)$ & $437.8(318.8)$ & $24.4(24.4)$ & $411.6(434.2)$ \\
$\quad$ Men & & & & & 0.42 & 0.31 \\
$\quad$ Women & 0.011 & 0.011 & 0.86 & 0.17 & 0.35 & 0.06 \\
\hline
\end{tabular}


preparations from 41 randomly selected cases (11 men and nine women from the SATET+ve group and 12 men and nine women from the SATET-ve group) disclosed no significant abnormalities, and in particular, mitochondria appeared structurally normal in all cases.

\section{Discussion}

Histological examination in our study disclosed no consistent abnormalities, although non-specific changes were seen occasionally, as noted by others (table 1). Edwards $e t a l^{18}$ found abnormalities such as fibre necrosis, regenerating fibres, nemaline rods, targetoid fibres, and histochemical changes such as single fibre glycogen depletion in $81 \%$ of biopsies (mainly from the tibialis anterior) in patients with chronic fatigue syndrome, although these were also present in about a third of normal control samples. A high prevalence of such changes was also noted by Connolly et $a l^{10}$ in a subgroup of patients with chronic fatigue syndrome in whom myalgia and muscle tenderness were prominent. Notably, these abnormalities were found in the extensor digitorum communis, a muscle which would not normally be affected by inactivity to the same extent as a leg muscle. One of our patients had an inflammatory infiltrate, and it would seem that inflammation and class I MHC expression may occur occasionally in biopsies from patients with chronic fatigue syndrome. ${ }^{14}{ }^{18}$ This is of some interest, as we have argued previously that some forms of chronic fatigue syndrome may follow a previous virally mediated inflammatory myopathy, ${ }^{25}$ suggesting a continuum with polymyositis which could also encompass benign postinfection polymyositis. ${ }^{26}$ Muscular function might be expected to deteriorate in patients with chronic fatigue syndrome, who are by definition relatively inactive. The magnitude and nature of the consequences of physical inactivity deserve emphasis, as some of the symptoms experienced by patients with chronic fatigue syndrome are reminiscent of those resulting from bed rest or immobilisation. ${ }^{2}$ Complete immobilisation of the quadriceps results in reduced muscle protein turnover, ${ }^{27}$ detectable within six hours, ${ }^{28}$ and healthy young males lost $20 \%$ of static strength within one week of immobilisation in one study, ${ }^{29}$ whereas in another, cardiorespiratory capacity was impaired by $25 \%$ after three weeks of bed rest. ${ }^{30}$ Lack of physical activity in normal subjects increases the sense of mental and physical effort on subsequent exertion, reduces the desire for exercise, ${ }^{31}$ and impairs neuropsychological function, despite normal environmental stimulation. ${ }^{32}$ Autonomic changes, including postural hypotension and defective thermoregulation may also occur. ${ }^{33}$ Changes in muscle fibre size and fibre type proportions with inactivity are variable, and differ in humans and experimental animals, and under different clinical and experimental situations. For example, immobilisation after surgery or injury to a limb results in sequential changes in muscle architecture, with an initial shift of fibres with type 1 characteristics to type 2, fol- lowed by muscle fibre atrophy, which can affect either fibre type, or both, causing loss of muscle bulk and strength. ${ }^{34-36}$ Conversely, prolonged bed rest $^{37}{ }^{38}$ or unilateral lower limb unloading in young healthy subjects ${ }^{39} 40$ produced no consistent changes in fibre type distribution, but was associated with fibre atrophy and reduction in cross sectional area of muscles, whereas muscle unweighting experiments in rats produced a shift from slow twitch (mitochondria rich) to fast twitch fibres. ${ }^{41}$ The results of the histometric analysis of biopsies from our patients with chronic fatigue syndrome, however, did not reflect the effects of inactivity. There was no evidence of a shift from type 1 to type 2 fibres; indeed, type 1 fibre predominance was more common than type 2 predominance, and fibre atrophy was uncommon, with fibre hypertrophy being present in more than half the cases. Others have noted fibre hypertrophy in qualitative ${ }^{116}$ and quantitative $^{1718}$ studies of biopsies from patients with chronic fatigue syndrome, although some authors have reported significant muscle fibre atrophy. ${ }^{12} 1315$ These discrepancies might reflect various factors, including the case mix of patients with chronic fatigue syndrome studied, and use of qualitative rather than quantitative analysis in some series. The aetiology and relevance of fibre hypertrophy found in the present study, and in some earlier reports, is presently unclear. By contrast with the whole group of patients with chronic fatigue syndrome studied, the patients with abnormal lactate responses to exercise did have significantly fewer type 1 fibres (and correspondingly more type 2 fibres) than patients with normal SATET (table 3), whereas there was no difference in mean atrophy factors. This difference was still more pronounced in the group of patients with the most abnormal lactate responses to exercise (table 4). Could this type 1 fibre deficiency in the SATET+ve patients have been the result of a greater degree of inactivity in this subgroup? This is possible, but there is no evidence to support the contention. As discussed above, whereas a shift from type 1 to type 2 fibres can be found with immobilisation, Ferretti et $a l^{\beta 8}$ recently reported that six weeks of total bed rest in healthy young males did not result in significant changes in fibre type proportions, and only a non-significant trend to fibre atrophy; others have reported similar findings. ${ }^{37}$ None of the patients in this study were bedbound or severely immobile at the time of investigation, and we reported previously that the SATET+ve patients did not differ from the SATET-ve patients in demographic characteristics such as employment status, and were no more deconditioned in terms of heart rate responses to exercise. ${ }^{20}$ Other studies have also failed to show that patients with chronic fatigue syndrome are significantly less fit in terms of cardiac responses and oxygen consumption during exercise than normal sedentary subjects. ${ }^{42}{ }^{43}$ This relative deficiency of mitochondria rich type 1 fibres may account for the left shift in anaerobic threshold in the subgroup of patients with increased lactate responses to exercise. ${ }^{19}$ 
However, there were frequent examples of patients with abnormal SATET who had a normal proportion of type 1 fibres, so this finding cannot be used to predict the situation in individual cases. There is some evidence that type 2 fibre predominance, and thus a relative deficiency of type 1 fibres, might have biological relevance. Type 2 fibres are stronger for their cross sectional area than type 1 fibres $^{44}$ and a preponderance of type 2 fibres might preserve static strength in patients with chronic fatigue syndrome while reducing endurance.Those with type 2 predominance tend to have poorer exercise endurance, which probably results from the relative inefficiency of ATP production in type 2 fibres compared with the mitochondria rich type 1 fibres. ${ }^{45}$ Inherited fibre type characteristics may determine athletic aptitude and performance, ${ }^{46}$ but inherited or acquired changes in fibre types may also predispose to disease. Type 2 fibre predominance has been reported previously in patients with "idiopathic exertional myalgia and fatigue ${ } 47$ and in a recent study from Taiwan, ${ }^{48}$ military recruits who had had heatstroke complicated by rhabdomyolysis had significantly higher proportions of type 2 fibres than those with heatstroke who did not develop this complication. In addition, as in the present study, there was a correlation between the proportion of type 2 fibres and blood lactate responses to exercise. It is interesting to note in this context that abnormal lactate responses to exercise were documented some 50 years ago in servicemen said to have "neurocirculatory asthenia". ${ }^{49}$ Our findings suggest that abnormal lactate responses to exercise in some patients with chronic fatigue syndrome are unlikely to be due solely to inactivity. Although we found no abnormalities of mitochondrial structure, the relative deficiency of type 1 muscle fibres is in keeping with other reports concerning reduced oxidative metabolism and mitochondrial enzyme activity in muscle in some patients with chronic fatigue syndrome. ${ }^{5-750}$ Whether this deficiency is due to changes in muscle activity patterns or more fundamental disorders of mitochondrial function remains to be determined.

We thank Dr Adrian Burgess for help with the original analysis of the histometric data and Professor Archie Young and Professor Richard Edwards for helpful discussions and information concerning changes in muscle relating to inactivity. RL and LA gratefully acknowledge the support of the Persistent Virus Disease Research Foundation.

1 Fukuda K, Straus SE, Hickie I, et al. The chronic fatigue syndrome: a comprehensive approach to its definition and syndrome: a comprehensive approach to
study. Ann Intern Med 1994;121:953-9.

2 Chronic fatigue syndrome. Report of a joint working group of the Royal Colleges of Physicians, Psychiatrists and General Practitioners. London: Royal College of Physicians Publication Unit, 1996.

3 Stokes M, Cooper R, Edwards R. Normal strength and fatiguability in patients with effort syndrome. BMf 1988;297: 1014-8.

4 Lloyd A, Gandevia S, Hales J. Muscle performance, voluntary activation, twitch properties and perceived effort in normal subjects and patients with the chronic fatigue synnormal subjects and patients with

5 Arnold DL, Bore PJ, Radda GK, et al. Excessive intracellular acidosis of skeletal muscle on exercise in a patient with a post-viral exhaustion/fatigue syndrome. A ${ }^{31} \mathrm{P}$ nuclear magnost-viral exhaustion/fatigue syndrome. A

6 Wong R, Lopaschuk G, Zhu G, et al. Skeletal muscle metabolism in the chronic fatigue syndrome. In vivo metabolism in the chronic fatigue syndrome. In vivo assessment by ${ }^{31} \mathrm{P}$ nuclear ma
copy. Chest 1992;102:1716-22.
7 McCully KK, Natelson BH, Iotti S, et al. Reduced oxidative muscle metabolism in chronic fatigue syndrome. Muscle muscle metabolism in

Nerve 1996;19:621-5.
8 Jamal GA, Hansen S. Electrophysiological studies in the post-viral fatigue syndrome. $\mathcal{F}$ Neurol Neurosurg Psychiatry 1985;48:691-4

9 Roberts L, Byrne E. Single fibre EMG studies in chronic fatigue syndrome: a reappraisal. $f$ Neurol Neurosurg Psychiatry 1994;57:375-6.

10 Connolly S, Smith D, Doyle D, et al. Chronic fatigue: electromyographic and neuropathological evaluation. $\mathcal{f}$ Neurol 1993;240:435-8.

11 Behan PO, Behan WMH, Bell EJ. The post-viral fatigue syndrome - an analysis of the findings in 50 cases. F Infect 1985;10:211-22.

12 Byrne E, Trounce I, Dennett X. Chronic relapsing myalgia (?post viral): clinical, histological and biochemical studies. (?post viral): clinical, histological

Aust $N Z$ F Med 1985;15:305-8.
13 Byrne E, Trounce I. Chronic fatigue and myalgia syndrome: mitochondrial and glycolytic studies in skeletal muscle. $\mathcal{f}$ mitochondrial and glycolytic studies in skel

14 Karpati G, Carpenter S, Weller B, et al. Muscle biopsy experience in the chronic fatigue syndrome [abstract]. $\mathcal{F}$ Neurol Sci 1990;98(suppl):96.

15 Behan WMH, More IAR, Behan PO. Mitochondrial abnormalities in the postviral fatigue syndrome. Acta Neuropathol (Berl) 1991;83:61-5.

16 Grau JM, Casademont J, Pedrol E, et al. Chronic fatigue syndrome: studies on skeletal muscle. Clin Neuropathol 1992;11:329-32.

17 Preedy VR, Smith DG, Salisbury JR, et al. Biochemical and muscle studies in patients with acute onset post-viral fatigue syndrome. F Clin Pathol 1993;46:722-6.

18 Edwards R, Gibson H, Clague J, et al. Muscle physiology and histopathology in chronic fatigue syndrome. In: Kleinman A, Straus S, eds. Chronic fatigue syndrome. Chichester: man A, Straus S, eds. Chronic

19 Lane RJM, Woodrow D, Archard LC. Lactate responses to exercise in chronic fatigue syndrome. $\mathcal{f}$ Neurol Neurosurg Psychiatry 1994;57:662-3.

20 Lane RJM, Burgess AP, Flint J, et al. Exercise responses and psychiatric disorder in chronic fatigue syndrome. $B M F$ 1995;311:544-5.

21 Sharpe M, Archard L, Banatvala J, et al. Chronic fatigue syndrome: guidelines for research. $\mathcal{F} R$ Soc Med 1991;84: $118-21$.

22 Nashef L, Lane RJM. Screening for mitochondrial cytopathies: the sub-anaerobic threshold exercise test (SATET). F Neurol Neurosurg Psychiatry 1989;52:1090-4. muscle disease. New York: Marcel Dekker, 1996:35-9.

4 Dubowitz V. Definition of pathological changes seen in muscle biopsies. In: Muscle biopsy. A practical approach, 2nd muscle biopsies. In: Muscle biopsy. A practic

25 Bowles NE, Bayston TA, Zhang H-Y, et al. Persistence of enteroviral RNA in muscle biopsy samples suggests that some cases of chronic fatigue syndrome result from a previous inflammatory viral myopathy. 7 Med 1993;24:14560.

26 Schwartz MS, Swash M, Gross M. Benign postinfection polymyositis. BMF 1978;ii:1256-7.

27 Gibson JNA, Halliday D, Morrison WL, et al. Decrease in human quadriceps muscle protein turnover consequent upon leg immobilisation. Clin Sci 1987;72:503-9.

28 Booth F. Physiologic and biochemical effects of immobilisation on muscle. Clin Orthop 1987;10:15-20.

29 Muller E. Influence of training and inactivity on muscle strength. Arch Phys Med Rehabil 1970;51:449-52.

30 Saltin B, Blomquist G, Mitchell J, et al. Response to exercise after bed rest and training: a longitudinal study of adaptive changes in oxygen transport and body composition. Circuchanges in oxygen transport and
lation 1968;38(suppl 7):1-55.

31 Folgering $\mathrm{H}$, von Herwaarden C. Exercise limitations in patients with pulmonary diseases. Int $\mathcal{f}$ Sports Med 1994;15:107-11

32 Zuber J, Wilgosh L. Prolonged immobilisation of the body: changes in performance and the electroencephalogram. Science 1963;140:306-8.

33 Greenleaf J, Kozlowski S. Physiological consequences of reduced physical activity during bed rest. Exerc Sport Sci Rev 1982;10:84-119.

34 Jaffe D, Terry R, Spiro A. Disuse atrophy of skeletal muscle. f Neurol Sci 1978;35:189-200.

35 Young A, Stokes M. Reflex inhibition of muscle activity and the morphological consequences of inactivity. In: Biochemthe morphological consequences of inactivity. In: Biochem-
istry of exercise VI. Champaign, Illinois: Human Kinetics Publishers, 1986:531-44. (International Series on Sports Sciences, Volume 16.)

36 Young A. Strength and power. In: J Grimley-Evans, T Franklin Williams, eds. Oxford textbook of geriatric medicine. Oxford University Press, 1992:597-601

37 Hikida RS, Gollnick PD, Dudley GA, et al. Structural and metabolic characteristics of human skeletal muscle following 30 days of simulated microgravity. Aviat Space Environ Med 1989; 60:664-70.

38 Ferretti G, Antonutto G, Denis C, et al. The interplay of central and peripheral factors in limiting maximal $\mathrm{O}_{2}$ consumption in man after prolonged bed rest. F Physiol 1997; 501:677-86.

39 Hather BM, Adams GR, Tesch PA, et al. Skeletal muscle responses to lower limb suspension in humans. $\mathcal{F} A p p l$ Physiol 1992;72:1493-8.

40 Berg HE, Dudley GA, Hather B, et al. Work capacity and metabolic and morphologic characteristics of the human 
quadriceps muscle in response to unloading. Clin Physiol 1993;13:337-47.

41 McDonald KS, Fitts RH. Effect of hindlimb unloading on rat soleus fibre force, stiffness and calcium sensitivity. $\mathcal{F}$ Appl Physiol 1995;79:168-75.

42 Gibson H, Carroll N, Clague JE, et al. Exercise performance and fatiguability in patients with chronic fatigue syndrome. f Neurol Neurosurg Psychiatry 1993;56:993-8.

43 Sisto SA, LaManca J, Cordero DL, et al. Metabolic and cardiovascular effects of a progressive exercise test in patients with chronic fatigue syndrome. $A m$ f $\mathrm{Med}$ 1996;100:634-40.

44 Young A. The relative isometric strength of type 1 and type 2 muscle fibres in the human quadriceps. Clin Physio 1984;4:23-32.

45 Ball-Burnett M, Green HJ, Houston ME. Energy metabolism in human slow and fast twitch fibres during prolonged lism in human slow and 1991;437:257-67.
46 Mero A, Jaakola L, Komi PV. Relationships between muscle fibre characteristics and physical performance capacity in trained athletic boys. F Sports Science 1991;9:161-71.

47 Telerman-Toppet N, Bacq M, Khoubesserian P, et al. Type 2 fibre predominance in muscle cramp and exertional myalgia. Muscle Nerve 1985;8:563-7.

48 Hsu Y-D, Lee W-H, Chang M-k, et al. Blood lactate threshold and type II fibre predominance in patients with exertional heatstroke. $f$ Neurol Neurosurg Psychiatry 1997; 62:182-7.

49 Cohen ME, Consalazio F, Johnson RE. Blood lactate response during moderate exercise in neurocirculatory asthenia, anxiety neurosis, or effort syndrome. $\mathcal{F}$ Clin Invest 1947;26:339-43.

50 Edwards R, Newham D, Peters T. Muscle biochemistry and pathophysiology in postviral fatigue syndrome. $\mathrm{Br} \mathrm{Med} \mathrm{Bull}$ 1991;47:826-37.

\section{Fournal of Neurology Neurosurgery and Psychiatry - http://www.jnnp.com}

Visitors to the world wide web can now access the fournal of Neurology Neurosurgery and Psychiatry either through the BMJ Publishing Group's home page (http://www.bmjpg.com) or directly by using its individual URL (http://www.jnnp.com). There they will find the following:

- Current contents list for the journal

- Contents lists of previous issues

- Members of the editorial board

- Subscribers' information

- Instructions for authors

- Details of reprint services.

A hotlink gives access to:

- BMJ Publishing Group home page

- British Medical Association web site

- Online books catalogue

- BMJ Publishing Group books.

The web site is at a preliminary stage and there are plans to develop it into a more sophisticated site. Suggestions from visitors about features they would like to see are welcomed. They can be left via the opening page of the BMJ Publishing Group site or, alternatively, via the journal page, through "about this site". 